\title{
SIKAP PELANGGAN LISTRIK PASCABAYAR KABUPATEN BANGKALAN MENGENAI SOSIALISASI PROGRAM LISTRIK PINTAR PT PLN (PERSERO) RANTING BANGKALAN
}

\author{
Amanda Syafitri, Yuli Nugraheni \\ Universitas Katolik Widya Mandala Surabaya \\ J1. Dinoyo 42-44 Surabaya, 60265 \\ Email : amandasyafitrii@yahoo.co.id, yulinugraheni@ukwms.ac.id
}

\begin{abstract}
Abstrak
Penelitian dengan judul Sikap Pelanggan Listrik Pascabayar Kabupaten Bangkalan Mengenai Sosialisasi Program Listrik Pintar PT PLN (Persero) Ranting Bangkalan, bertujuan untuk mengetahui bagaimana sikap pelanggan listrik pascabayar Kabupaten Bangkalan mengenai sosialisasi program listrik pintar PT PLN (Persero) Ranting Bangkalan. Pemilihan lokasi berdasarkan data yang diperoleh, menunjukkan bahwa tunggakan listrik terbesar berada pada Kabupaten Bangkalan, sehingga perlu adanya strategi untuk mengubah sikap. Sosialisasi bertujuan untuk mengubah sikap pelanggan listrik pascabayar agar mau mengubah sikap untuk beralih ke listrik pintar, sehingga memerlukan evaluasi bagaimana sikap pelanggan listrik pascabayar. Sikap ditinjau dari tiga komponen yaitu kognitif, afektif dan konatif yang berdasarkan elemen komunikasi dalam sosialisasi yaitu komunikator, komunikan, pesan, saluran dan noise. Penelitian ini merupakan penelitian kuantitatif deskriptif. Peneliti menggunakan metode penelitian survei dengan menggunakan kuesioner sebagai alat pengumpul data. Hasil dari penelitian ini menunjukkan sikap pelanggan listrik pascabayar memiliki kecenderungan yang negatif, sehingga responden cenderung tidak memberikan dukungan terhadap sosialisasi program listrik pintar. Pelanggan listrik pascabayar Kabupaten Bangkalan mengetahui dan menyetujui sosialisasi program listrik pascabayar, namun tidak memiliki kecenderungan untuk beralih.
\end{abstract}

Kata kunci : Sikap, Sosialisasi program listrik pintar, PT PLN (Persero) Ranting Bangkalan.

\begin{abstract}
Research about Postpaid Electricity Customer Behavior In Bangkalan District About Listrik Pintar Program Socialization PT PLN (Persero) Bangkalan Area is purposed to know how postpaid electricity customer behavior in Bangkalan district. The choice of location based on obtained data showed that the biggest arrears electricity is in Bangkalan district, so that need a strategy to change the behavior. Socialization of this program is aimed to change customer behavior by switching to Listrik Pintar. Behavior divided to three component that are cognitive, affective, and conative which is based on communication element in socialization that is communicator, communicant, message, channel and noise. This research is quantitative descriptive research. Survey method by questionnaire as data collection tool. The result of this research showed that postpaid electricity customer behavior have negative trend so that the respondent was not tend to give support towards Listrik Pintar program socialization. Postpaid electricity customer in Bangkalan district was knew and agreed about postpaid electricity program socialization, but had not tend to switch.
\end{abstract}

Keywords: behavior, Listrik Pintar program socialization, PT PLN (Persero) Bangkalan Area

\section{Latar Belakang Masalah}

Kajian penelitian ini berangkat dari sikap yang menggunakan teori S-O-R. Teori S-O-R merupakan singkatan dari Stimulus Organism - Response, efek dalam teori ini merupakan stimulus khusus, seseorang dapat mengharapkan dan memperkirakan kesesuaian antara pesan dan reaksi dari komunikan. Objek material yang menyusun teori S-O-R meliputi komponen-komponen sikap yaitu kognitif, afektif dan konatif. Teori S-O-R berfokus pada proses komunikasi sehingga mampu menunjukkan bagaimana mengubah perilaku sikap dari komunikan (Effendy, 2007:254). Maka peneliti menggunakan teori S-O-R untuk membedah penelitian, karena memiliki fokus kepada bagaimana mengubah sikap melalui komponen sikap.

Penelitian ini berbasis pada sikap yang 
bertujuan sebagai bentuk evaluasi dari sebuah aspek di lingkungan sekitar. Seorang komunikan, dalam penelitian ini adalah publik dapat merespon secara positif maupun negatif mengenai suatu objek. Terdapat tiga respon yaitu respon kognitif (apa yang diyakini), respon afektif (penyataan afeksi) dan respon konatif (tindakan dan pernyataan mengenai objek). Perlu adanya komunikasi yang efektif, agar sikap dapat dibentuk sesuai dengan apa yang direncanakan (Azwar, 2011: 6-8)

Pengukuran sikap dapat diukur dengan melihat efek dari proses komunikasi tersebut. Efek kognitif adalah efek yang pertama timbul yang bertujuan memberikan pesan pada komunikan. Komunikan diharapkan menjadi tahu pesan yang disampaikan kepadanya dan mengalami perubahan persepsi atau perubahan pendapat. Efek afektif adalah efek lanjutan dari efek kognitif saat terjadi perubahan sikap penerima pesan dalam menanggapi fenomena tertentu misalnya muncul rasa suka atau tidak suka. Efek konatif merupakan tahap akhir dari response penerima pesan terhadap suatu pesan. Pada level konatif, setelah publik mengetahui dan merasakan suatu pesan, pada tahap selanjutnya penerima pesan melakukan tindakan tertentu yang berkaitan dengan pesan tersebut, baik secara fisik maupun non fisik (Azwar, 2011: 24-28).

Dalam hal ini, komunikator dan pesan memiliki peran besar dalam membentuk sikap dari publik yang disasar. Perubahan sikap publik merupakan bentuk dari hasil response berdasarkan rangsangan dari stimulus. Sehingga sikap merupakan hasil dari sebab akibat rangsangan stimuli, apabila rangsangan stimuli tidak mendapatkan perhatian dari publik, maka perubahan sikap tidak akan sesuai dengan yang diharapkan oleh komunikator.

Dalam penelitian ini humas sebagai komunikator perlu merencanakan komunikasi yang strategis dalam menyusun pesan, melalui apa pesan disampaikan dan bagaimana pesan disampaikan kepada publik, sehingga dapat menghasilkan sikap publik yang diharapkan perusahaan (Effendy, 2007:256). Sama halnya dengan Perusahaan Listrik Negara (PLN), sebagai satu-satunya penyedia listrik negara, tentu perlu membina hubungan baik antara perusahaan dan publik sehingga dapat memaksimalkan pelayanan.

Dengan publik yang luas cakupannya, yaitu seluruh Indonesia maka perlu adanya hubungan baik antara perusahaan dan publik. Hal ini tidak luput dari komunikasi yang dilakukan oleh pihak Humas, apabila terjadi permasalahan atau memberikan sosialisasi terkait pelayanan dan perubahan kebijakan. Sosialisasi dikemas dalam program Nangkring Bareng yang diberikan sesuai dengan kebutuhan dan karakter dari publik. Jika berbeda lokasi, maka akan ada perbedaan bagaimana pesan dikemas dan disalurkan kepada publik. Contohnya pada saat 
Nangkring Bareng di daerah Madura dan Jember.

Nangkring Bareng merupakan sosialisasi yang dibuat secara kelompok dan hanya dilakukan selama enam bulan sekali, dengan mengundang opinion leader salah satunya yang telah dilakukan pada bulan Agustus 2017 di Kecamatan Socah. Mengundang kurang lebih 40 orang yang menjadi opinion leader, contohnya seperti tokoh agama dan perangkat desa (wawancara dengan Umar, Manajer PT PLN (Persero) Ranting Bangkalan, 23 Oktober 2017)

Sosialisasi tersebut dilakukan untuk mengkomunikasikan serta mengedukasi masyarakat mengenai Listrik Pintar dan kewajiban untuk membayar tagihan. Manajer PT PLN (Persero) Ranting Bangkalan turut menjelaskan mengenai pembayaran Listrik Pintar, cara beralih dan kebijakan subsidi.

Diakui bahwa dalam hal membentuk sikap, tidak hanya komunikator yang berperan. Pesan perlu dikemas dengan baik sehingga perhatian dari publik dapat diperoleh. Sehingga pesan dapat dipahami oleh publik dan menghasilkan sikap yang diharapkan oleh komunikator. Komunikator perlu mengemas pesan agar mudah diterima oleh komunikan agar dapat mencapai efek yang diinginkan. Mengingat komunikasi selalu bersifat intensional, komunikasi yang efektif harus dapat mencapai tujuan yang diinginkan. Tujuan tersebut dapat bervariasi. Untuk komunikasi publik, tujuan dapat berupa informasi, persuasi atau sebagai hiburan. Sementara dalam komunikasi kelompok, tujuan dapat berupa pencapaian kesepakatan untuk menyelesaikan masalah dan mencapai segala sesuatu yang dicita-citakan. (Beebe, Susan and Diana, 2011:6)

Berdasarkan hasil wawancara dengan Endang Wahyuni, Karyawan Humas PT PLN (Persero) Distribusi Jawa Timur, ditemukan bahwa sosialisasi dilakukan sesuai dengan kebutuhan, hal ini juga dikonfirmasi oleh Manajer PT PLN (Persero) Ranting Bangkalan yang melakukan sosialisasi lebih menyasar kepada Listrik Pintar yang memiliki segmentasi kepada warga daerah Madura khususnya Kabupaten Bangkalan yang belum beralih ke listrik pra bayar atau Listrik Pintar.

Maka pada penelitian ini, peneliti menggunakan pelanggan listrik pascabayar sebagai organism, karena merupakan target utama dari sosialisasi guna menimbulkan perubahan sikap untuk mau beralih dari listrik pascabayar menjadi listrik pra bayar, yang telah dikomunikasikan oleh PT PLN (Persero) Ranting Bangkalan.

Listrik Pintar atau biasa disebut dengan listrik pra bayar, merupakan pengalihan metode pembayaran dari pascabayar menjadi prabayar atau yang biasa disebut dengan listrik meteran. Program ini muncul sejak tahun 2010 dan menghadapi tanggapan positif dan negatif dari masyarakat sehingga sosialisasi terus dilakukan baik secara kelompok maupun door to door. Salah 
satunya dialami oleh Kota Madura yang memiliki permasalahan tunggakan tertinggi jika dibandingkan dengan kota-kota lain (www.pln.co.id, diakses pada tanggal 12 Oktober 2017).

Banyak masyarakat yang menunggak, yaitu tidak melakukan pembayaran sesuai dengan jangka waktu yang telah ditentukan, terjadi di daerah Madura. PT PLN area Madura memiliki total tunggakan terbesar seIndonesia pada tahun 2014. Penyebab utama tunggakan itu terjadi, yaitu banyaknya masyarakat yang menggunakan listrik secara ilegal. Saat ini PT PLN tengah memfokuskan permasalahan tunggakan di area Madura dan sekitarnya. Hal ini diungkapkan juga oleh Dwi Kusnanto selaku General Manager PT PLN (Persero) Distribusi Jawa Timur saar memberikan sambutan dalam program Komunikasi dan Informasi Setelah Senam pada tanggal 4 Agustus 2017, mengenai masalah mengedukasi masyarakat melalui sosialisasi. Menganggap bahwa perlu adanya proses edukasi kepada masyarakat secara mendalam. Sehingga muncul kesepemahaman dan solusi untuk masalah tunggakan yang dialami.

Hal ini juga diperkuat dengan jika dibandingkan dengan tunggakan pada rayon lain yaitu Sampang, Sumenep dan Pamekasan. Rayon Bangkalan memiliki tunggakan paling tinggi, yaitu sebesar 5,2 Miliar pada akhir tahun 2014 dan meningkat dari akhir tahun 2014 sampai 2016.
Berdasarkan data dari metronews dan tempo, menunjukkan adanya peningkatan tunggakan PLN Ranting Bangkalan dari tahun 2014 2016. Tahun 2015 tunggakan PLN meningkat dari 5,2 M menjadi 7,25 M. sedangkan tahun 2016 meningkat kembali menjadi 9,27M.

Sosialisasi Listrik Pintar terus dilakukan dengan tujuan perubahan sikap dari publik untuk segera beralih. Karena pada dasarnya, program pelayanan ini ditujukan agar tunggakan dapat teratasi dan masyarakat juga dapat merasakan manfaat Listrik Pintar, yaitu dapat mengatur anggaran rumah tangganya. Namun muncul ketakutan pada masyarakat dengan adanya program Listrik Pintar, maka akan mempersempit peluang untuk dapat melakukan penunggakan, karena pada sistem pembayaran Listrik Pintar menggunakan sistem pembayaran di awal (pra-bayar).

Menurut Heider (1985) dalam Liliweri (2011:165) mengatakan bahwa ketika kepercayaan atau keyakinan dalam keadaan yang tidak seimbang, maka akan mengalami tekanan untuk mengubah sikap lalu berusaha menangani tekanan itu. Perlu adanya kepercayaan antara publik dengan perusahaan agar publik mampu menerima stimulus dari perusahaan.

Stimulus atau pesan pada penelitian ini adalah pengalihan metode pembayaran dari pascabayar menjadi prabayar yang diaplikasikan dalam sosialisasi PT PLN (Persero) Ranting Bangkalan. PLN membina 
hubungan antara perusahaan dan publiknya melalui sosialisasi yang dilakukan oleh PLN. Agar terjadi komunikasi dua arah yang sehat. Hal ini sesuai dengan definisi humas menurut Dr. Rex Harlow yaitu fungsi membangun jembatan komunikasi antara perusahaan dan publiknya (Ruslan, 2016:16).

Sebenarnya respon dari masyarakat tidak selalu bersifat negatif atau mengalami penolakan, ada juga pelanggan yang memutuskan untuk beralih karena merasa mendapatkan manfaat dari adanya Listrik Pintar/prabayar. Masyarakat merasa Listrik Pintar memiliki berbagai kemudahan, terutama kemudahan dalam mengatur tingginya rekening listrik dan kemudahan dalam pembayaran. Berdasarkan data-data dan fenomena yang terjadi, peneliti ingin mengetahui mengenai sikap pelanggan listrik pascabayar mengenai sosialisasi listrik pra bayar, menggunakan indikator elemen sikap yaitu komponen kognitif, afektif dan konatif. Stimulus atau pesan yang disampaikan kepada publik, bisa saja diterima atau mungkin ditolak. Komunikasi akan berlangsung apabila ada perhatian dari publik. Proses selanjutnya, publik mengerti. Kemampuan untuk mengerti inilah yang mampu melanjutkan ke proses berikutnya yaitu perubahan sikap.

Berdasarkan rumusan masalah dan tujuan yang ingin dicapai dari penelitian ini, maka metode penelitian yang digunakan adalah metode penelitian deskriptif dengan menggunakan pendekatan kuantitatif.
Pendekatan kuantitatif adalah riset yang menggambarkan atau menjelaskan suatu masalah yang hasilnya dapat digeneralisasikan. Sehingga penelitian ini digunakan untuk menggambarkan realitas yang sedang terjadi tanpa menjelaskan hubungan antar variabel (Kriyantono, 2012:69). Jadi, dalam penelitian kuantitatif dengan tipe penelitian deskriptif, peneliti hanya akan meneliti sikap pelanggan listrik pascabayar Kabupaten Bangkalan mengenai sosialisasi program Listrik Pintar PT PLN (Persero) Kabupaten Bangkalan.

Metode yang digunakan peneliti dalam penelitian ini adalah metode survei. Penelitian survei adalah penelitian yang mengambil sampel dari satu populasi dan menggunakan kuesioner sebagai alat pengumpul data yang pokok (Silalahi, 2012 : 293).

\section{Sikap}

Secord \& Backman (1964) dalam buku Azwar, mendefinisikan sikap sebagai keteraturan tertentu dalam hal perasaan (afeksi), pemikiran (kognisi) dan predisposisi tindakan (konasi) seseorang terhadap suatu aspek di lingkungan sekitarnya (Azwar, 2011:5). Sikap sendiri memiliki tiga komponen (Azwar, 2011:24-28). Komponenkomponen tersebut terdiri dari :

1. Komponen Kognitif

Komponen kognitif merupakan komponen yang berisi kepercayaan seseorang 
mengenai apa yang berlaku atau apa yang benar bagi objek sikap. Kepercayaan datang dari apa yang telah diketahui. Saat kepercayaan telah terbentuk, maka akan menjadi dasar pengetahuan komunikan berdasarkan apa yang diharapkan dari objek tertentu. Namun, terkadang kepercayaan juga dapat terbentuk dari kurang atau tiadanya informasi yang benar mengenai objek yang dihadapi.

\section{Efek Afektif}

Komponen afektif merupakan komponen yang menyangkut masalah emosional subjektif seseorang terhadap suatu sikap. Secara umum, komponen ini disamakan dengan perasaan yang dimiliki terhadap sesuatu.

\section{Efek Konatif}

Komponen perilaku atau komponen konatif dalam struktur sikap menunjukkan bagaimana perilaku atau kecenderungan perilaku yang ada dalam diri seseorang berkaitan dengan objek sikap yang dihadapinya. Konsistensi antara kepercayaan sebagai komponen kognitif, perasaan sebagai komponen afektif, dengan tendensi perilaku sebagai komponen konatif seperti itulah yang menjadi landasan dalam usaha penyimpulan sikap.

Menurut Azwar (2011:88), sikap mempunyai arah, artinya sikap terpilah menjadi dua arah kesetujuan, yaitu apakah setuju atau tidak setuju, apakah mendukung atau tidak mendukung, apakah memihak atau tidak memihak terhadap sesuatu atau seseorang sebagai objek.

1. Orang yang setuju, mendukung atau memihak terhadap suatu objek sikap berarti memiliki sikap yang arahnya positif.

2. Orang yang tidak setuju atau tidak mendukung dikatakan memiliki sikap yang arahnya negatif.

Selain itu, terdapat faktor yang mempengaruhi sikap terhadap objek sikap, (Azwar, 2016:30-38) adalah Pengalaman pribadi yang dapat menjadi dasar pembentukan sikap, pengalaman pribadi haruslah meninggalkan kesan yang kuat. Kemudian pengaruh orang lain yang dianggap penting, pada umumnya individu cenderung untuk memilki sikap yang konformis atau searah dengan sikap orang yang dianggap penting agar menghindari adanya konflik. Lalu pengaruh kebudayaan, kebudayaan telah mewarnai sikap anggota masyarakatnya, karena kebudayaanlah yang memberi corak pengalaman individu-individu masyarakat asuhannya.

\section{Elemen Komunikasi Dalam Sosialisasi}

Menurut Robbins dan Judge (2013:520) salah satu kekuatan dalam memainkan peranan yang penting dalam mempertahankan suatu budaya adalah sosialisasi. Sosialisasi adalah suatu proses 
yang mangadaptasikan anggota organisasi pada budaya organisasi tersebut. Berikut ini adalah macam-macam sosialisasi yang dapat diaplikasikan:

\section{Formal vs. Informal}

Semakin banyak karyawan baru dipisahkan dari pengaturan pekerjaan yang sedang berlangsung dan dibedakan dalam beberapa cara untuk membuat peran pendahulunya secara eksplisit, semakin banyak sosialisasi yang bersifat formal. Program orientasi dan pelatihan khusus adalah contohnya. Sosialisasi informal menempatkan karyawan baru tersebut langsung ke pekerjaan, dengan sedikit atau tanpa perhatian khusus.

\section{Individual vs collective}

Publik akan di sosialisasi secara individu, sehingga menunjukkan bagaimana profesionalitas dari institusi. Bisa juga menggunakan pilihan dengan mengelompokkan publik dan memprosesnya sebagai persamaan pengalaman

\section{Fixed vs Variable}

Ini mengacu pada jadwal waktu di mana pendatang baru melakukan transisi dari orang luar ke orang dalam. Jadwal tetap menetapkan tahap transisi standar. Ini mencirikan program pelatihan rotasi.

\section{Serial vs. Random}

Sosialisasi serial ditandai dengan penggunaan role model yang melatih dan mendorong publik untuk memahami norma atau nilai yang berlaku. Program mentoring adalah contohnya. Dalam sosialisasi acak, panutan sengaja tidak digunakan. (Robbins dan Judge, 2013: 522).

Dalam penelitian ini, sosialisasi yang digunakan oleh PT PLN (Persero) Ranting Bangkalan adalah individual vs collective, yaitu dengan cara komunikasi baik secara interpersonal maupun massa. Secara face to face, online dan menggunakan target Kepala Desa juga Pemuka Agama.

Komunikasi adalah sebuah proses dalam bertukar pemaknaan. Memahami bagaimana proses ini berkerja, maka ada beberapa elemen yang perlu dipahami.

Berikut elemen komunikasi (De Vito, 2012: 8-16):

1. Komunikator-Komunikan

Komunikator dan komunikan memiliki fungsi yang saling berpengaruh satu sama lain dalam komunikasi antar individu. Menurut Lau,Chiu, \& Hong dalam buku De Vito, mengungkapkan siapa anda, apa yang anda ketahui, apa yang anda percayai, nilai apa yang dipahami, apa yang diinginkan, apa yang telah anda ucapkan, dan perilaku anda semua dipengaruhi apa yang anda lihat, bagaimana anda mengatakannya, pesan apa yang diterima dan bagaimana anda menerima pesan tersebut. Kemampuan dalam berbicara meliputi, suara, kedekatan fisik, pendekatan yang sesuai adalah bagian dari kemampuan. Kemampuan dalam berkomunikasi dapat mengolah hubungan yang bermakna dalam persahabatan, cinta, keluarga dan pekerjaan. 


\section{Pesan}

Pesan adalah tanda yang disajikan sebagai stimulus dari komunikan dan diterima dengan salah satu panca indra, seperti audio (mendengar), visual (melihat), berkenaan dengan peraba (sentuhan), penciuman (bau), perasa atau kombinasi dari indra. Komunikasi dapat dilakukan melalui telepon, webcam atau, face to face.

\section{Saluran}

Saluran dari komunikasi adalah media yang digunakan untuk menyalurkan pesan. Seperti jembatan yang menghubungkan antara komunikator dan komunikan. Contoh dari saluran adalah kontak face to face, telepon, email, media sosial, facebook, film, televisi dam lain-lain.

\section{Noise \\ Noise merupakan stimulus yang} mengganggu pengiriman atau pemahaman pesan audiens. Macam noise antara lain (De Vito, 2012: 14) :

a. Physical noise, meliputi gangguan teknis seperti suara maupun cahaya dari luar ruangan yang mengalihkan perhatian audiens.

b. Physiological noise, gangguan yang terjadi baik antara komunikator ataupun komunikan, Seperti suara yang tidak jelas, tidak ingat, kesulitan secara visual dan tidak mendengarkan. c. Psychological noise, gangguan ini terjadi dalam diri komunikator maupun komunikan apabila bias, menolak pesan dan tidak mempercayai pesan yang didapat.

d. Semantic noise, gangguan yang terjadi ketika komunikator dan komunikan memiliki pemaknaan pesan yang berbeda. Contohnya seperti perbedaan bahasa ataupun istilah yang sulit dipahami oleh komunikan.

Dalam penelitian ini, noise yang memiliki kemungkinan untuk terjadi hanya pada gangguan semantic dan psychological karena sosialisasi yang dilakukan oleh PT PLN (Persero) Ranting Bangkalan lebih dominan dilakukan secara face to face dan kelompok.

\section{Konteks}

Konteks merupakan setting dimana pesan tersampaikan yang berpengaruh pada perhatian audiens. Ada tiga aspek dalam konteks yaitu :

a. Physical setting, berhubungan dengan lokasi, pemilihan waktu, hari serta hal-hal detail lainnya seperti cahaya, suhu ruangan dan jumlah orang didalam satu ruangan

b. Historical setting, berhubungan dengan event yang terjadi sehingga memunculkan kegiatan komunikasi publik. Dapat juga melalui pesan instant yang tidak dapat diketahui kapan komunikan membaca 
pesan tersebut, karena terkirim dan diterima pada waktu yang berbeda.

c. Psychological setting, berhubungan dengan mood, perasaan, maupun attitude komunikator maupun komunikan yang mempengaruhi bagaimana pesan dikirimkan atau diterima.

d. Cultural setting, berhubungan dengan kepercayaan, nilai, agama, hirarki sosial, serta peran dalam masyarakat

Dalam penelitian ini, elemen konteks tidak digunakan karena sosialisasi PT PLN (Persero) Ranting Bangkalan tidak dilakukan pada latar lokasi yang jelas. Sosialisasi lebih dominan dilakukan secara interpersonal antara komunikator dan komunikan dan hanya satu desa yang mendapat sosialisasi secara kelompok.

\section{Gambaran Umum Subyek Penelitian}

Subjek pada penelitian ini adalah pelanggan listrik pascabayar Kabupaten Bangkalan yang mengetahui mengenai sosialisasi program listrik pintar PT PLN (Persero) Ranting Bangkalan. Wilayah Bangkalan dipilih karena memiliki tunggakan paling besar se-Indonesia. Pelanggan listrik pascabayar Kabupaten Bangkalan dipilih karena merupakan target dari sosialisasi listrik pintar PT PLN (Persero) Ranting Bangkalan.

Berdasarkan hasil data yang diperoleh dari Umar Arif selaku manajer PT PLN (Persero) Ranting Bangkalan, jumlah pelanggan listrik pascabayar pada tahun 2017 yaitu sebesar
73.221 rumah tangga yang tersebar di 11 Kecamatan. Pelanggan listrik pascabayar merupakan salah satu dari target sosialisasi program listrik pintar.

\section{Uji Validitas dan Reliabilitas}

Uji validitas digunakan untuk mengetahui kelayakan butir-butir dalam suatu daftar pernyataan dalam mendefinisikan suatu variabel. Uji validitas dilakukan pada setiap butir pertanyaan. Uji validitas dalam penelitian ini menggunakan teknik Product Moment dengan bantuan Statistical Package for Social Science (SPSS). Hasil r hitung akan dibandingkan dengan $r$ tabel. Jika $r$ tabel $>r$ hitung maka dapat dikatakan valid (Sujarweni dan Endrayanto, 2012:177). Dalam penelitian ini, peneliti menggunakan IBM SPSS versi 24.

Suatu alat ukur memiliki reliabilitas atau keandalan atau dapat dipercaya jika hasil pengukurannya tidak berubah-ubah dan dapat diandalkan karena penggunaan alat ukur tersebut berulang-ulang tetap akan memberikan hasil yang relatif sama (Silalahi, 2012:236-238).

\section{Analisa Data}

Pemilihan identitas responden yang peneliti buat pada kuesioner disesuaikan dengan hal-hal yang dapat mempengaruhi sikap pelanggan listrik pascabayar mengenai program Listrik Pintar. Pengaruh yang dimaksud adalah jenis kelamin, usia, 
kecamatan, pendidikan terakhir, pengeluaran perbulan yang dapat menentukan kelas sosial.

Tabel IV.5.

Deskripsi Karakteristik Responden Berdasarkan Jenis Kelamin

\begin{tabular}{|c|l|c|c|}
\hline No. & Jenis kelamin & Jumlah & Persentase \\
\hline 1. & Laki-laki & 39 & $39 \%$ \\
\hline 2. & Perempuan & 61 & $61 \%$ \\
\hline & Total & 100 & $100 \%$ \\
\hline
\end{tabular}

Sumber : Kuesioner Identitas Responden No.1

Tabel IV.5 menunjukkan total responden dilihat dari jenis kelamin menyebutkan bahwa responden yang lebih banyak dijumpai adalah perempuan yaitu sebanyak $61 \%$ sedangkan responden yang lebih sedikit adalah laki-laki yaitu sebanyak $39 \%$.

Tabel IV.6.

Deskripsi Karakteristik Responden Berdasarkan Usia

\begin{tabular}{|c|c|c|c|}
\hline No. & $\begin{array}{c}\text { Jenis } \\
\text { kelamin }\end{array}$ & Jumlah & Persentase \\
\hline 1. & $18-25$ th & 13 & $13 \%$ \\
\hline 2. & $26-35$ th & 56 & $56 \%$ \\
\hline 3. & $36-45$ th & 21 & $21 \%$ \\
\hline 4. & $46-55$ th & 4 & $4 \%$ \\
\hline 5. & $>55$ th & 6 & $6 \%$ \\
\hline & Total & 100 & $100 \%$ \\
\hline
\end{tabular}

Sumber : Kuesioner Identitas Responden No.2

Berdasarkan Tabel IV.6 menunjukkan bahwa mayoritas pelanggan listrik pascabayar yang menjadi responden, mengetahui sosialisasi program listrik pintar adalah berumur 26 - 35 tahun yaitu sebesar $56 \%$.
Tabel IV.7.

Deskripsi Karakteristik Responden Berdasarkan Kecamatan

\begin{tabular}{|c|c|c|c|}
\hline No. & Kecamatan & Jumlah & Persentase \\
\hline 1. & Kec. Arosbaya & 8 & $8 \%$ \\
\hline 2. & Kec. Bangkalan & 27 & $27 \%$ \\
\hline 3. & Kec. Burneh & 12 & $12 \%$ \\
\hline 4. & Kec. Galis & 1 & $1 \%$ \\
\hline 5. & Kec. Geger & 8 & $8 \%$ \\
\hline 6. & Kec. Klampis & 10 & $10 \%$ \\
\hline 7. & Kec. Labang & 1 & $1 \%$ \\
\hline 8. & Kec. Sepulu & 7 & $7 \%$ \\
\hline 9. & Kec. Socah & 13 & $13 \%$ \\
\hline 10. & Kec. Tanah Merah & 8 & $8 \%$ \\
\hline 11. & Kec. Tragah & 5 & $5 \%$ \\
\hline & Total & 100 & $100 \%$ \\
\hline
\end{tabular}

Sumber : Kuesioner Identitas Responden No.3

$\begin{array}{llll}\text { Jika dilihat pada Tabel IV.7 } & \end{array}$ menunjukkan bahwa persentase terbanyak ada pada kecamatan Bangkalan, yaitu sebanyak 27\%. Hal ini disebabkan oleh jumlah pendudukan Kecamatan Bangkalan paling banyak jika dibandingkan dengan kecamatan lain. Pembagian responden berdasarkan perhitungan kuota sampling pada Bab III.

Tabel IV.8.

Deskripsi Karakteristik Responden Berdasarkan Pendidikan

\begin{tabular}{|c|l|c|c|}
\hline No. & \multicolumn{1}{|c|}{ Pendidikan } & Jml & Persentase \\
\hline 1. & SD & 10 & $10 \%$ \\
\hline 2. & SMP & 26 & $26 \%$ \\
\hline 3. & SMA & 43 & $43 \%$ \\
\hline 4. & Diploma & 13 & $13 \%$ \\
\hline 5. & Sarjana & 7 & $7 \%$ \\
\hline 6. & Lain-lain (tidak sekolah) & 1 & $1 \%$ \\
\hline & Total & 100 & $100 \%$ \\
\hline
\end{tabular}

Sumber : Kuesioner Identitas Responden No.4

Berdasarkan tabel IV.8 menunjukkan total responden dilihat dari pendidikan terakhir, dapat diketahui bahwa mayoritas pelanggan listrik pascabayar yang mengetahui sosialisasi program listrik pintar 
berpendidikan SMA yaitu sebanyak $43 \%$ sedangkan responden yang paling sedikit dibandingkan dengan yang lain adalah yang tidak mengenyam pendidikan yaitu hanya $1 \%$ dari keseluruhan total responden. Hal ini disebabkan oleh responden memilih untuk langsung berkerja daripada melanjutkan ke perkuliahan.

Tabel IV.9.

Deskripsi Karakteristik Responden Berdasarkan Pengeluaran

\begin{tabular}{|c|c|c|c|}
\hline No. & Pengeluaran & Jumlah & Persentase \\
\hline 1. & $<700.000$ & 1 & $1 \%$ \\
\hline 2. & $700.000-1.000 .000$ & 25 & $25 \%$ \\
\hline 3. & $1.000 .000-1.500 .000$ & 34 & $34 \%$ \\
\hline 4. & $1.500 .000-2.000 .000$ & 32 & $32 \%$ \\
\hline 5. & $2.000 .000-3.000 .000$ & 7 & $7 \%$ \\
\hline 6. & $>3.000 .000$ & 1 & $1 \%$ \\
\hline & Total & 100 & $100 \%$ \\
\hline
\end{tabular}

Sumber : Kuesioner No.5

Berdasarkan Tabel IV.9 ditemukan bahwa responden mayoritas berada pada SES C2 yaitu middle SES. menyatakan bahwa mayoritas pelanggan listrik pascabayar yang menjadi responden yang mengetahui sosialisasi program listrik pintar memiliki kategori SES C2 yaitu sebanyak 34\% sedangkan responden yang lebih sedikit dibandingkan dengan yang lain adalah yang memiliki kategori SES E dan SES A hanya sebanyak $1 \%$.

Untuk SES A pengeluaran keluarga Rp 3 juta ke atas. Sedangkan SES B adalah keluarga yang berpengeluaran antara Rp 2 juta - 3 juta. Kemudian SES C1 adalah kelompok pengeluaran Rp 1,5 juta - 2 juta, sedangkan C2 adalah keluarga yang memiliki pengeluaran Rp 1 juta - 1,5 juta. SES D adalah keluarga yang memiliki pengeluaran Rp 700 ribu - 1 juta sedangkan yang terakhir adalah SES E adalah keluarga yang memiliki pengeluaran sebesar kurang dari Rp 700.000.

Menurut Badan Pusat Statistik dalam buku Kabupaten Bangkalan Dalam Angka 2017, pengeluaran rata-rata per kapita sebulan penduduk Kabupaten Bangkalan tahun 2016 lebih tinggi jika dibandingkan pada tahun 2015. Persentase penduduk dengan pengeluaran $14,47 \%$ di tahun 2016 sedangkan pada tahun 2015 angka tersebut adalah $12,07 \%$.

Elemen komunikator pada komponen kognitif merupakan pengetahuan responden mengenai siapa yang mengkomunikasikan sosialisasi dan pengetahuan yang telah diberikan oleh komunikator. Dalam penelitian ini, komunikator dalam sosialisasi dalah karyawan PT PLN (Persero) Ranting Bangkalan.

Sikap responden pada komponen kognitif yang berdasarkan elemen komunikator selengkapnya dijelaskan pada tabel berikut ini : 
Tabel IV.10.

Deskripsi Elemen Komunikator pada Komponen Kognitif

\begin{tabular}{|c|c|c|c|c|c|c|c|c|}
\hline \multicolumn{3}{|c|}{ Identitas Kognitif } & \multicolumn{4}{|c|}{ Jawaban Responden } & \multirow[t]{2}{*}{ Total } & \multirow[t]{2}{*}{ Mean } \\
\hline & & & STS & TS & $\mathrm{S}$ & SS & & \\
\hline \multirow[t]{2}{*}{ KGKT6 } & \multirow{2}{*}{$\begin{array}{l}\text { Saya mengetahui bahwa } \\
\text { karyawan PLN memberikan } \\
\text { informasi mengenai listrik pintar } \\
\text { (listrik pulsa/token) }\end{array}$} & Frek & 0 & 0 & 85 & 15 & \multirow[t]{2}{*}{100} & \multirow[t]{2}{*}{3,15} \\
\hline & & $\%$ & 0 & 0 & $85 \%$ & $15 \%$ & & \\
\hline \multirow[t]{2}{*}{ KGKT7 } & \multirow[b]{2}{*}{$\begin{array}{l}\text { Saya mengetahui bahwa } \\
\text { karyawan PLN memberikan } \\
\text { informasi mengenai metode } \\
\text { pembayaran listrik pintar (listrik } \\
\text { pulsa/token), yaitu membayar di } \\
\text { agen maupun ATM }\end{array}$} & Frek & 0 & 35 & 60 & 5 & \multirow[t]{2}{*}{100} & \multirow[t]{2}{*}{2,7} \\
\hline & & $\%$ & 0 & $35 \%$ & $60 \%$ & $5 \%$ & & \\
\hline \multirow[t]{2}{*}{ KGKT8 } & \multirow{2}{*}{$\begin{array}{l}\text { Saya mengetahui bahwa } \\
\text { karyawan PLN memberikan } \\
\text { informasi mengenai tujuan listrik } \\
\text { pintar (listrik pulsa/token) yaitu } \\
\text { agar dapat mengatur pengeluaran. }\end{array}$} & Frek & 3 & 44 & 51 & 2 & \multirow[t]{2}{*}{100} & \multirow[t]{2}{*}{2,52} \\
\hline & & $\%$ & 3 & $44 \%$ & $51 \%$ & $2 \%$ & & \\
\hline \multicolumn{8}{|c|}{ Rata-rata Komponen Kognitif Berdasarkan Elemen Komunikator } & 2.79 \\
\hline
\end{tabular}

Sumber: Olahan Peneliti

Berdasarkan tabel IV.10 komponen kognitif berkaitan dengan pengetahuan seseorang terhadap suatu objek (Azwar, 2016 : 24-25). Pada pernyataan "Saya mengetahui bahwa karyawan PLN memberikan informasi mengenai listrik pintar (listrik pulsa/token)". Tingkat pengetahuan responden positif, hal ini dapat terlihat juga dari $100 \%$ responden menyatakan setuju. Tidak hanya sekedar memberikan informasi saja, namun beberapa kali diingatkan karena adanya faktor orang lain sehingga responden - dapat dengan mudah mengingat hal tersebut. Pernyataan ini memiliki mean yang positif yaitu sebesar 3,15. Mayoritas responden mengetahui bahwa karyawan PLN telah memberikan informasi mengenai listrik pintar. Nilai rata-rata responden pada komponen kognitif yang berdasarkan elemen komunikator adalah 2,79 sehingga menunjukkan bahwa responden memiliki tingkat pengetahuan yang tinggi mengenai komunikator dalam sosialisasi program listrik pintar.

Tabel IV.11

Deskripsi Elemen Komunikan pada Komponen Kognitif

\begin{tabular}{|c|c|c|c|c|c|c|c|c|}
\hline \multicolumn{3}{|c|}{ Identitas Kognitif } & \multicolumn{4}{|c|}{ Jawaban Responden } & \multirow[t]{2}{*}{ Total } & \multirow[t]{2}{*}{ Mean } \\
\hline & & & STS & TS & $\mathbf{S}$ & SS & & \\
\hline \multirow{2}{*}{ KGKK9 } & \multirow{2}{*}{$\begin{array}{l}\text { Saya mengetahui bahwa target dari sosialisasi program } \\
\text { listrik pintar (listrik pulsa/token) adalah pelanggan listrik } \\
\text { pascabayar (meteran) }\end{array}$} & Frek & 0 & 15 & 85 & 0 & \multirow[t]{2}{*}{100} & \multirow[t]{2}{*}{2,85} \\
\hline & & $\%$ & 0 & $15 \%$ & $85 \%$ & 0 & & \\
\hline \multirow[t]{2}{*}{ KGKK10 } & \multirow{2}{*}{$\begin{array}{l}\text { Saya mengetahui bahwa target dari sosialisasi program } \\
\text { listrik pintar (listrik pulsa/token) adalah pelanggan listrik } \\
\text { pascabayar (meteran) yang kesulitan dalam mengatur } \\
\text { pengeluaran }\end{array}$} & Frek & 2 & 52 & 46 & 0 & \multirow[t]{2}{*}{100} & \multirow[t]{2}{*}{2,44} \\
\hline & & $\%$ & $2 \%$ & $52 \%$ & $46 \%$ & 0 & & \\
\hline
\end{tabular}

Sumber: Olahan Peneliti 
Berdasarkan Tabel IV.11 berdasarkan dua pernyataan tersebut, pernyataan "Saya mengetahui bahwa target dari sosialisasi program listrik pintar (listrik pulsa/token) adalah pelanggan listrik pascabayar (meteran)". Sebanyak $85 \%$ responden menyatakan setuju terhadap pernyataan tersebut, karena mengetahui target sosialisasi program listrik pintar. Sedangkan 15\% responden menyatakan tidak setuju terhadap pernyataan tersebut. Sebanyak 54\% menyata-kan tidak setuju dengan pernyataan responden mengetahui bahwa target dari sosialisasi program listrik pintar (listrik pulsa/token) adalah pelanggan listrik pascabayar (meteran) yang kesulitan dalam mengatur pengeluaran, sedangkan $46 \%$ lainnya menyatakan setuju terhadap penyataan tersebut.

Tabel IV.12.

Deskripsi Elemen Pesan pada Komponen Kognitif

\begin{tabular}{|c|c|c|c|c|c|c|c|c|}
\hline \multicolumn{3}{|c|}{ Identitas Kognitif } & \multicolumn{4}{|c|}{ Jawaban Responden } & \multirow[t]{2}{*}{ Total } & \multirow[t]{2}{*}{ Mean } \\
\hline & & & STS & TS & $\mathbf{S}$ & SS & & \\
\hline \multirow[t]{2}{*}{ KGP11 } & \multirow{2}{*}{$\begin{array}{l}\text { Saya mengetahui bahwa pesan dari sosialisasi program listrik pintar } \\
\text { (listrik pulsa/token) merupakan pengalihan pembayaran dari meteran } \\
\text { menjadi listrik pulsa }\end{array}$} & Frek & 0 & 17 & 82 & 1 & \multirow[t]{2}{*}{100} & \multirow[t]{2}{*}{2,84} \\
\hline & & $\%$ & 0 & $17 \%$ & $82 \%$ & $1 \%$ & & \\
\hline \multirow[t]{2}{*}{ KGP12 } & \multirow{2}{*}{$\begin{array}{l}\text { Saya mengetahui pesan mengenai pelanggan lebih mudah } \\
\text { mengendalikan pemakaian listrik bila menggunakan listrik pintar } \\
\text { (listrik pulsa/token) }\end{array}$} & Frek & 1 & 44 & 55 & 0 & \multirow[t]{2}{*}{100} & \multirow[t]{2}{*}{2,54} \\
\hline & & $\%$ & $1 \%$ & $44 \%$ & $55 \%$ & 0 & & \\
\hline \multirow[t]{2}{*}{ KGP13 } & \multirow{2}{*}{$\begin{array}{l}\text { Saya mengetahui pesan tentang pemakaian listrik pintar (listrik } \\
\text { pulsa/token) dapat disesuaikan dengan anggaran belanja. }\end{array}$} & Frek & 3 & 38 & 59 & 0 & \multirow[t]{2}{*}{100} & \multirow[t]{2}{*}{2,56} \\
\hline & & $\%$ & $3 \%$ & $38 \%$ & $59 \%$ & 0 & & \\
\hline \multirow[t]{2}{*}{ KGP14 } & \multirow{2}{*}{$\begin{array}{l}\text { Saya mengetahui pesan tentang pembelian token listrik dapat } \\
\text { dilakukan via online ATM dan Outlet. }\end{array}$} & Frek & 0 & 26 & 69 & 5 & \multirow[t]{2}{*}{100} & \multirow[t]{2}{*}{2,79} \\
\hline & & $\%$ & 0 & $26 \%$ & $69 \%$ & $5 \%$ & & \\
\hline \multicolumn{3}{|c|}{ Rata-rata Komponen Kognitif berdasarkan Ele } & & & & & & 2,68 \\
\hline
\end{tabular}

Sumber: Olahan Peneliti

Berdasarkan Tabel IV.12 pada pernyataan "Saya mengetahui bahwa pesan dari sosialisasi program listrik pintar (listrik pulsal token) merupakan pengalihan pembayaran dari meteran menjadi listrik pulsa". Sebanyak $83 \%$ dari responden menyatakan setuju mengenai pernyataan tersebut, sedangkan sebanyak $17 \%$ responden menyatakan tidak setuju mengenai pesan tersebut. Informasi ini adalah pesan yang pertama kali disampaikan oleh PLN mengenai listrik pintar.
Sehingga informasi ini merupakan hal dasar yang memiliki peluang besar bagi responden untu mengetahuinya. Pernyataan ini memiliki mean sebesar 2,84. Hal ini menunjukkan bahwa tingkat pengetahuan responden positif, mengenai pesan sosialisasi program listrik pintar berupa pengalihan pembayaran dari meteran menjadi listrik pulsa. Selain itu, responden juga terus mengingat karena beberapa tetangga mereka mulai menggunakan listrik pintar/pulsa. 
Tabel IV.13.

Deskripsi Elemen Saluran pada Komponen Kognitif

\begin{tabular}{|c|c|c|c|c|c|c|c|c|}
\hline \multicolumn{3}{|c|}{ Identitas Kognitif } & \multicolumn{4}{|c|}{ Jawaban Responden } & \multirow[t]{2}{*}{ Total } & \multirow[t]{2}{*}{ Mean } \\
\hline & & & STS & TS & $\mathbf{S}$ & SS & & \\
\hline \multirow[t]{2}{*}{ KGS15 } & \multirow{2}{*}{$\begin{array}{l}\text { Saya mengetahui bahwa PLN telah mensosialisasikan } \\
\text { program listrik pintar (listrik pulsa/token) melalui melalui } \\
\text { media website PT PLN (pln.co.id) }\end{array}$} & Frek & 2 & 68 & 30 & 0 & \multirow[t]{2}{*}{100} & \multirow[t]{2}{*}{2,28} \\
\hline & & $\%$ & $2 \%$ & $68 \%$ & $30 \%$ & 0 & & \\
\hline \multirow[t]{2}{*}{ KGS16 } & \multirow{2}{*}{$\begin{array}{l}\text { Saya mengetahui bahwa PLN telah mensosialisasikan } \\
\text { program listrik pintar (listrik pulsa/token) melalui media } \\
\text { sosialisasi bersama kepala desa dan pemuka agama. }\end{array}$} & Frek & 7 & 53 & 40 & 0 & \multirow[t]{2}{*}{100} & \multirow[t]{2}{*}{2,33} \\
\hline & & $\%$ & $7 \%$ & $53 \%$ & $40 \%$ & 0 & & \\
\hline \multirow[t]{2}{*}{ KGS17 } & \multirow{2}{*}{$\begin{array}{l}\text { Saya mengetahui bahwa PLN telah mensosialisasikan } \\
\text { program listrik pintar (listrik pulsa/token) melalui karyawan } \\
\text { PLN yang melakukan cek meteran. }\end{array}$} & Frek & 0 & 8 & 92 & 0 & \multirow[t]{3}{*}{100} & \multirow[t]{2}{*}{2,92} \\
\hline & & $\%$ & 0 & $8 \%$ & $92 \%$ & 0 & & \\
\hline \multicolumn{3}{|c|}{ Komponen Kognitif berdasarkan Elemen } & & & & & & 2.51 \\
\hline
\end{tabular}

Sumber: Olahan Peneliti

Berdasarkan tabel IV.13 pernyataan

"Saya mengetahui bahwa PLN telah mensosialisasikan program listrik pintar (listrik pulsa/token) melalui melalui media website PT PLN (pln.co.id)" Sebanyak 70\% responden menyatakan tidak setuju sedangkan $30 \%$ responden menyatakan setuju. Berdasarkan wawancara peneliti dengan Farid, menunjukkan bahwa responden tidak mengetahui isi dari website karena tidak memahami cara mengakses dan tidak memiliki waktu luang untuk mengakses.
Padahal sosialisasi telah dikemas melalui website yang dapat diakses melalui pln.co.id. Sehingga memungkinkan pelanggan untuk mendapatkan informasi lebih cepat namun tetap akurat. Panduan di website juga menampilkan simulasi bagaimana prosedur pembelian token listrik, sehingga pelanggan akan dengan mudah memahami informasi. Pernyataan ini memiliki mean yang negatif yaitu sebesar 2,28 sehingga memiliki kecenderungan yang negatif.

Tabel IV.14.

Deskripsi Elemen Noise pada Komponen Kognitif

\begin{tabular}{|c|c|c|c|c|c|c|c|c|}
\hline \multicolumn{3}{|c|}{ Identitas Kognitif } & \multicolumn{4}{|c|}{ Jawaban Responden } & \multirow[t]{2}{*}{ Total } & \multirow[t]{2}{*}{ Mean } \\
\hline & & & STS & TS & S & SS & & \\
\hline \multirow[t]{2}{*}{ KGN18 } & \multirow{2}{*}{$\begin{array}{l}\text { Saya mengetahui bahwa sosialisasi PLN mengenai listrik } \\
\text { pintar (listrik pulsa/token)_menggunakan bahasa yang } \\
\text { mudah dimengerti. }\end{array}$} & Frek & 0 & 33 & 67 & 0 & \multirow[t]{2}{*}{100} & \multirow[t]{2}{*}{2,67} \\
\hline & & $\%$ & $0 \%$ & $33 \%$ & $67 \%$ & $0 \%$ & & \\
\hline \multirow[t]{2}{*}{ KGN19 } & \multirow{2}{*}{$\begin{array}{l}\text { Saya mengetahui bahwa informasi mengenai listrik pintar } \\
\text { dapat diakses melalui website pln.co.id }\end{array}$} & Frek & 3 & 61 & 36 & 0 & \multirow[t]{2}{*}{100} & \multirow[t]{2}{*}{2,33} \\
\hline & & $\%$ & $3 \%$ & $61 \%$ & $36 \%$ & $0 \%$ & & \\
\hline \multirow[t]{2}{*}{ KGN20 } & \multirow{2}{*}{$\begin{array}{l}\text { Saya mengetahui bahwa karyawan PLN menyampaikan } \\
\text { informasi yang akurat }\end{array}$} & Frek & 2 & 20 & 77 & 1 & \multirow[t]{2}{*}{100} & \multirow[t]{2}{*}{2,77} \\
\hline & & $\%$ & $2 \%$ & $20 \%$ & $77 \%$ & $1 \%$ & & \\
\hline
\end{tabular}

Sumber: Olahan Peneliti

Berdasarkan tabel IV.14, menunjukkan bahwa gangguan yang mungkin dapat dialami oleh responden tergolong rendah. Ditunjukkan pada pernyataan "Saya mengetahui bahwa sosialisasi PLN mengenai listrik pintar (listrik pulsa/token) menggunakan bahasa yang mudah dimengerti" sebanyak $67 \%$ responden menyatakan setuju, sedangkan 33\% lainnya menyatakan tidak setuju terhadap pernyataan tersebut. Pernyataan ini didasari oleh semantic noise yaitu gangguan yang terjadi ketika komuni-kator dan komunikan memiliki pemaknaan pesan yang berbeda. Hal ini bisa terjadi apa-bila komunikator menggunakan bahasa atau istilah yang sulit dimegerti oleh responden. Namun berdasarkan data di lapangan menunjukkan bahwa peluang terjadinya semantic noise tergolong rendah, karena memiliki mean sebesar 2,67 sehingga tingkat pengetahuan responden terhadap penggunaan bahasa yang mudah dimengerti adalah positif. 
Tabel IV.15.

Deskripsi Elemen Komunikator pada Komponen Afektif

\begin{tabular}{|c|c|c|c|c|c|c|c|c|}
\hline \multicolumn{3}{|c|}{ Identitas Afektif } & \multicolumn{4}{|c|}{ Jawaban Responden } & \multirow[t]{2}{*}{ Total } & \multirow[t]{2}{*}{ Mean } \\
\hline & & & STS & TS & $\mathbf{S}$ & SS & & \\
\hline \multirow[t]{2}{*}{ AKT21 } & \multirow{2}{*}{$\begin{array}{l}\text { Saya menyetujui bahwa karyawan PLN memberikan informasi } \\
\text { mengenai listrik pintar (listrik pulsa/token) }\end{array}$} & Frek & 2 & 15 & 74 & 9 & \multirow[t]{2}{*}{100} & \multirow[t]{2}{*}{2,9} \\
\hline & & $\%$ & $2 \%$ & $15 \%$ & $74 \%$ & $9 \%$ & & \\
\hline \multirow[t]{2}{*}{ AKT22 } & \multirow{2}{*}{$\begin{array}{l}\text { Saya menyetujui bahwa karyawan PLN memberikan informasi } \\
\text { mengenai metode pembayaran listrik pintar (listrik pulsa/token), yaitu } \\
\text { membayar di agen maupun ATM }\end{array}$} & Frek & 0 & 43 & 56 & 1 & \multirow[t]{2}{*}{100} & \multirow[t]{2}{*}{2,58} \\
\hline & & $\%$ & 0 & $43 \%$ & $56 \%$ & $1 \%$ & & \\
\hline \multirow[t]{2}{*}{ AKT23 } & \multirow{2}{*}{$\begin{array}{l}\text { Saya menyetujui bahwa karyawan PLN memberikan informasi } \\
\text { mengenai tujuan listrik pintar (listrik pulsa/token) yaitu agar dapat } \\
\text { mengatur pengeluaran. }\end{array}$} & Frek & 2 & 48 & 50 & 0 & \multirow[t]{2}{*}{100} & \multirow[t]{2}{*}{2,48} \\
\hline & & $\%$ & $2 \%$ & $48 \%$ & $50 \%$ & 0 & & \\
\hline \multicolumn{8}{|c|}{ Rata-rata Komponen Afektif berdasarkan Elemen Komunikator } & 2,65 \\
\hline
\end{tabular}

Sumber: Olahan Peneliti

Berdasarkan tabel IV.15 pada pernyataan sedangkan 17\% lainnya menyatakan tidak "Saya menyetujui bahwa karyawan PLN setuju mengenai pernyataan tersebut. memberikan informasi mengenai listrik pintar (listrik pulsa/token)" sebanyak $83 \%$ Sehingga mean pada pernyataan ini memiliki menyatakan setuju, angka dengan kecenderungan yang positif yaitu sebesar 2,9.

Tabel IV.16.

Deskripsi Elemen Komunikan pada Komponen Afektif

\begin{tabular}{|c|c|c|c|c|c|c|c|c|}
\hline \multicolumn{3}{|c|}{ Identitas Afektif } & \multicolumn{4}{|c|}{ Jawaban Responden } & \multirow[t]{2}{*}{ Total } & \multirow[t]{2}{*}{ Mean } \\
\hline & & & STS & TS & $\mathbf{S}$ & SS & & \\
\hline \multirow[t]{2}{*}{ AKN24 } & \multirow{2}{*}{$\begin{array}{l}\text { Saya menyetujui bahwa target dari sosialisasi } \\
\text { program listrik pintar (listrik pulsa/token) adalah } \\
\text { pelanggan listrik pascabayar (meteran) }\end{array}$} & Frek & 0 & 13 & 86 & 1 & \multirow[t]{2}{*}{100} & \multirow[t]{2}{*}{2.88} \\
\hline & & $\%$ & 0 & $13 \%$ & $86 \%$ & $1 \%$ & & \\
\hline \multirow[t]{2}{*}{ AKN25 } & \multirow{2}{*}{$\begin{array}{l}\text { Saya menyetujui bahwa target dari sosialisasi } \\
\text { program listrik pintar (listrik pulsa/token) adalah } \\
\text { pelanggan listrik pascabayar (meteran) yang } \\
\text { kesulitan dalam mengatur pengeluaran }\end{array}$} & Frek & 2 & 61 & 37 & 0 & \multirow[t]{2}{*}{100} & \multirow[t]{2}{*}{2.35} \\
\hline & & $\%$ & $2 \%$ & $61 \%$ & $37 \%$ & 0 & & \\
\hline \multicolumn{8}{|c|}{ Rata-rata Komponen Afektif berdasarkan Elemen Komunikan } & 2.61 \\
\hline
\end{tabular}

Sumber: Olahan Peneliti

Berdasarkan tabel IV.16 pada pernyataan "Saya menyetujui bahwa target dari sosialisasi program listrik pintar (listrik pulsa/token) adalah pelanggan listrik pascabayar (meteran)" sebanyak $87 \%$ sedangkan $13 \%$ lainnya menyatakan tidak setuju terhadap pernyataan ini. Sehingga berdasarkan hasil temuan, menunjukkan bahwa responden memiliki tingkat responden menyatakan setuju,

persetujuan yang tinggi.

Tabel IV.17.

Deskripsi Elemen Pesan pada Komponen Afektif

\begin{tabular}{|c|c|c|c|c|c|c|c|c|}
\hline \multicolumn{3}{|c|}{ Identitas Afektif } & \multicolumn{4}{|c|}{ Jawaban Responden } & \multirow[t]{2}{*}{ Total } & \multirow[t]{2}{*}{ Mean } \\
\hline & & & STS & TS & $\mathbf{S}$ & SS & & \\
\hline \multirow[t]{2}{*}{ AP26 } & \multirow{2}{*}{$\begin{array}{l}\text { Saya menyetujui bahwa pesan dari sosialisasi } \\
\text { program listrik pintar (listrik pulsa/token) } \\
\text { merupakan pengalihan pembayaran dari meteran } \\
\text { menjadi listrik pulsa }\end{array}$} & Frek & 0 & 13 & 87 & 0 & \multirow[t]{2}{*}{100} & \multirow[t]{2}{*}{2,87} \\
\hline & & $\%$ & 0 & $13 \%$ & $87 \%$ & 0 & & \\
\hline \multirow[t]{2}{*}{ AP27 } & \multirow{2}{*}{$\begin{array}{l}\text { Saya menyetujui pesan mengenai pelanggan lebih } \\
\text { mudah mengendalikan pemakaian listrik bila } \\
\text { menggunakan listrik pintar (listrik pulsa/token) }\end{array}$} & Frek & 10 & 56 & 34 & 0 & \multirow[t]{2}{*}{100} & \multirow[t]{2}{*}{2,24} \\
\hline & & $\%$ & $10 \%$ & $56 \%$ & $34 \%$ & 0 & & \\
\hline \multirow[t]{2}{*}{ AP28 } & \multirow{2}{*}{$\begin{array}{l}\text { Saya menyetujui pesan tentang pemakaian listrik } \\
\text { pintar (listrik pulsa/token) dapat disesuaikan dengan } \\
\text { anggaran belanja }\end{array}$} & Frek & 9 & 61 & 30 & 0 & \multirow[t]{2}{*}{100} & \multirow[t]{2}{*}{2,21} \\
\hline & & $\%$ & $9 \%$ & $61 \%$ & $30 \%$ & 0 & & \\
\hline \multirow[t]{2}{*}{ AP29 } & \multirow{2}{*}{$\begin{array}{l}\text { Saya menyetujui pesan tentang pembelian token } \\
\text { dapat dilakukan via online, ATM dan outlet. }\end{array}$} & Frek & 0 & 22 & 77 & 1 & \multirow[t]{2}{*}{100} & \multirow[t]{2}{*}{2,79} \\
\hline & & $\%$ & 0 & $22 \%$ & $77 \%$ & $1 \%$ & & \\
\hline \multicolumn{8}{|c|}{ Rata-rata Komponen Afektif berdasarkan Elemen Pesan } & 2,52 \\
\hline
\end{tabular}

Sumber: Olahan Peneliti 
Berdasarkan tabel IV.17 pada pernyataan "Saya menyetujui bahwa pesan dari sosialisasi program listrik pintar (listrik pulsa/token) merupakan pengalihan pembayaran dari meteran menjadi listrik pulsa" sebanyak $87 \%$ responden menyatakan setuju, sedangkan $13 \%$ lainnya menyatakan tidak setuju terhadap pernyataan tersebut. Hal ini menunjukkan tingkat persetujuan yang cenderung positif, dari responden mengenai pengertian dari program listrik pintar.

Tabel IV.18.

Deskripsi Elemen Saluran pada Komponen Afektif

\begin{tabular}{|c|c|c|c|c|c|c|c|c|}
\hline \multicolumn{3}{|c|}{ Identitas Afektif } & \multicolumn{4}{|c|}{ Jawaban Responden } & \multirow[t]{2}{*}{ Total } & \multirow[t]{2}{*}{ Mean } \\
\hline & & & STS & TS & $\mathbf{S}$ & SS & & \\
\hline \multirow[t]{2}{*}{ AS30 } & \multirow{2}{*}{$\begin{array}{l}\text { Saya menyetujui bahwa PLN telah } \\
\text { mensosialisasikan program listrik pintar (listrik } \\
\text { pulsa/token) melalui media website PT PLN } \\
\text { (pln.co.id) }\end{array}$} & Frek & 3 & 79 & 18 & 0 & \multirow[t]{2}{*}{100} & \multirow[t]{2}{*}{2,15} \\
\hline & & $\%$ & $3 \%$ & $79 \%$ & $18 \%$ & $0 \%$ & & \\
\hline \multirow[t]{2}{*}{ AS31 } & \multirow{2}{*}{$\begin{array}{l}\text { Saya menyetujui bahwa PLN telah } \\
\text { mensosialisasikan program listrik pintar (listrik } \\
\text { pulsa/token) melalui media sosialisasi bersama } \\
\text { kepala desa dan pemuka agama. }\end{array}$} & Frek & 1 & 59 & 39 & 1 & \multirow[t]{2}{*}{100} & \multirow[t]{2}{*}{2,4} \\
\hline & & $\%$ & $1 \%$ & $59 \%$ & $39 \%$ & $1 \%$ & & \\
\hline \multirow[t]{2}{*}{ AS32 } & \multirow{2}{*}{$\begin{array}{l}\text { Saya menyetujui bahwa PLN telah } \\
\text { mensosialisasikan program listrik pintar (listrik } \\
\text { pulsa/token) melalui karyawan PLN yang } \\
\text { melakukan cek meteran. }\end{array}$} & Frek & 1 & 9 & 90 & 0 & \multirow[t]{2}{*}{100} & \multirow[t]{2}{*}{2,89} \\
\hline & & $\%$ & $1 \%$ & $9 \%$ & $90 \%$ & $0 \%$ & & \\
\hline \multicolumn{8}{|c|}{ Rata-rata Komponen Afektif berdasarkan Elemen Saluran } & 2,48 \\
\hline
\end{tabular}

Sumber: Olahan Peneliti

Berdasarkan tabel IV.18 pada pernyataan "Saya menyetujui bahwa PLN telah mensosialisasikan program listrik pintar (listrik pulsa/token) melalui melalui media website PT PLN (pln.co.id)" sebanyak 82\% responden menyatakan tidak setuju, sedangkan $18 \%$ lainnya menyatakan setuju mengenai PLN telah mensosialisasikan program listrik pintar (listrik pulsa/token) melalui media website PT PLN (pln.co.id). Jika dibandingkan dengan dua pernyataan lainnya, pernyataan tersebut memiliki tingkat persetujuan yang paling rendah.
Hal ini disebabkan karena saluran melalui website jarang diakses oleh responden, karena tidak memahami bagaimana cara mengakses. Mayoritas responden mengaku, apabila ingin menanyakan sesuatu mengenai kelistrikan, mereka akan langsung menghubungi call center PLN karena beranggapan akan lebih cepat ditangani. Pernyataan ini memiliki nilai mean yang cenderung negatif, yaitu sebesar 2,15 sehingga responden memiliki tingkat persetujuan yang cenderung negatif mengenai saluran melalui website. 
Tabel IV.19.

Deskripsi Elemen Noise pada Komponen Afektif

\begin{tabular}{|c|c|c|c|c|c|c|c|c|}
\hline \multicolumn{3}{|c|}{ Identitas Afektif } & \multicolumn{4}{|c|}{ Jawaban Responden } & \multirow[t]{2}{*}{ Total } & \multirow[t]{2}{*}{ Mean } \\
\hline & & & STS & TS & $\mathbf{S}$ & $\mathbf{S S}$ & & \\
\hline \multirow[t]{2}{*}{ AN33 } & \multirow{2}{*}{$\begin{array}{l}\text { Saya menyetujui bahwa sosialisasi PLN } \\
\text { mengenai listrik pintar (listrik pulsa/token) } \\
\text { menggunakan bahasa yang mudah dimengerti. }\end{array}$} & Frek & 0 & 37 & 62 & 1 & \multirow[t]{2}{*}{100} & \multirow[t]{2}{*}{2,64} \\
\hline & & $\%$ & $0 \%$ & $37 \%$ & $62 \%$ & $1 \%$ & & \\
\hline \multirow[t]{2}{*}{ AN34 } & \multirow{2}{*}{$\begin{array}{l}\text { Saya menyetujui bahwa informasi mengenai } \\
\text { listrik pintar dapat diakses melalui website } \\
\text { pln.co.id }\end{array}$} & Frek & 4 & 63 & 33 & 0 & \multirow[t]{2}{*}{100} & \multirow[t]{2}{*}{2,29} \\
\hline & & $\%$ & $4 \%$ & $63 \%$ & $33 \%$ & 0 & & \\
\hline \multirow[t]{2}{*}{ AN35 } & \multirow{2}{*}{$\begin{array}{l}\text { Saya menyetujui bahwa karyawan PLN } \\
\text { menyampaikan informasi yang akurat }\end{array}$} & Frek & 0 & 21 & 79 & 0 & \multirow[t]{2}{*}{100} & \multirow[t]{2}{*}{2,79} \\
\hline & & $\%$ & 0 & $21 \%$ & $79 \%$ & 0 & & \\
\hline \multicolumn{8}{|c|}{ Rata-rata Komponen Afektif berdasarkan Elemen Noise } & 2,57 \\
\hline
\end{tabular}

\section{Sumber: Olahan Peneliti}

Berdasarkan tabel IV.19, pada pernyataan mudah dimengerti. Mayoritas responden "Saya menyetujui bahwa sosialisasi PLN mengenai listrik pintar (listrik pulsa/token) menyatakan bahwa tidak ada istilah yang sulit dimengerti oleh responden. Pernyataan ini menggunakan bahasa yang mudah dimengerti” sebanyak $63 \%$ responden menyatakan setuju, sedangkan 37\% lainnya menyatakan tidak setuju terhadap sosialisasi PLN mengenai listrik pintar (listrik memiliki total mean sebanyak 2,64 sehingga tingkat persetujuan responden memiliki kecenderungan yang positif, maka peluang terjadinya noise memiliki tingkat yang rendah.

pulsa/token) menggunakan bahasa yang

Tabel IV.20.

Deskripsi Komponen Konatif

\begin{tabular}{|c|c|c|c|c|c|c|c|c|}
\hline \multicolumn{3}{|c|}{ Identitas Konatif } & \multicolumn{4}{|c|}{ Jawaban Responden } & \multirow[t]{2}{*}{ Total } & \multirow[t]{2}{*}{ Mean } \\
\hline & & & STS & TS & $\mathbf{S}$ & SS & & \\
\hline \multirow[t]{2}{*}{ KN36 } & \multirow{2}{*}{$\begin{array}{l}\text { Saya akan menggunakan listrik pintar (listrik } \\
\text { pulsa/token) karena mudah dalam melakukan } \\
\text { pembayaran }\end{array}$} & Frek & 9 & 70 & 21 & 0 & \multirow[t]{2}{*}{100} & \multirow[t]{2}{*}{2,12} \\
\hline & & $\%$ & $9 \%$ & $70 \%$ & $21 \%$ & 0 & & \\
\hline \multirow[t]{2}{*}{ KN37 } & \multirow{2}{*}{$\begin{array}{l}\text { Saya akan menggunakan listrik pintar (listrik } \\
\text { pulsa/token) karena dapat menghindari } \\
\text { tingginya harga rekening listrik meteran. }\end{array}$} & Frek & 33 & 47 & 20 & 0 & \multirow[t]{2}{*}{100} & \multirow[t]{2}{*}{1,87} \\
\hline & & $\%$ & $33 \%$ & $47 \%$ & $20 \%$ & 0 & & \\
\hline \multirow[t]{2}{*}{ KN38 } & \multirow{2}{*}{$\begin{array}{l}\text { Saya akan menggunakan listrik pintar (listrik } \\
\text { pulsa/token) karena dapat mengatur } \\
\text { pengeluaran rumah tangga sesuai dengan } \\
\text { kebutuhan. }\end{array}$} & Frek & 19 & 61 & 20 & 0 & \multirow[t]{2}{*}{100} & \multirow[t]{2}{*}{2,01} \\
\hline & & $\%$ & $19 \%$ & $61 \%$ & $20 \%$ & 0 & & \\
\hline \multicolumn{3}{|c|}{ Rata-rata Komponen Konatif } & & & & & & 2 \\
\hline
\end{tabular}

Sumber: Olahan Peneliti

Berdasarkan tabel IV.20 pada pernyataan "Saya akan menggunakan listrik pintar (listrik pulsa/token) karena mudah dalam melakukan pembayaran" sebanyak $79 \%$ responden menyatakan tidak setuju, sedangkan $21 \%$ responden menyatakan tidak setuju mengenai kecenderungan untuk beralih ke listrik pintar karena mudah dalam melakukan pembayaran. 
Berdasarkan tiga pernyataan yang telah dijabarkan, menunjukkan bahwa kecenderungan responden untuk beralih ke listrik pintar, memiliki kecenderungan yang negatif. Total rata-rata komponen konatif hanya sebesar 2 saja. Banyak faktor responden untuk memutuskan tidak beralih ke listrik pintar. Salah satunya adalah faktor kebiasaan menggunakan listrik meteran. Responden sudah terlalu lama menggunakan listrik meteran, beberapa responden mengungkapkan telah menggunakan listrik meteran selama 20 tahun.

Tabel IV.21 Hasil Rata-rata Variabel Sikap

\begin{tabular}{|c|c|c|}
\hline & Rata-rata & Keterangan \\
\hline Komponen Kognitif & 2,64 & Positif \\
\hline Komponen Afektif & 2,6 & Positif \\
\hline Komponen Konatif & 2 & Negatif \\
\hline Sikap keseluruhan & $\mathbf{2 , 4}$ & Negatif \\
\hline
\end{tabular}

Sumber : Olahan Peneliti

Berdasarkan Tabel IV.21 diketahui bahwa nilai rata-rata (mean) secara keseluruhan pada komponen kognitif adalah sebesar 2,64. Mean komponen kognitif termasuk dalam kategori positif yaitu 2,5 sampai 4. Dengan demikian, tingkat pengetahuan responden mengenai sosialisasi program listrik pintar adalah tinggi. Hal ini ditunjukkan dengan nilai rata-rata dari komponen kognitif.
Komponen kognitif merupakan komponen yang berisi kepercayaan seseorang mengenai apa yang berlaku atau apa yang benar bagi objek sikap. Kepercayaan datang dari apa yang telah diketahui. Saat kepercayaan telah terbentuk, maka akan menjadi dasar pengetahuan komunikan berdasarkan apa yang diharapkan dari objek tertentu (Azwar, 2011: 24). Mayoritas responden dalam penelitian ini mengetahui adanya sosialisasi program listrik pintar PT PLN (Persero) Ranting Bangkalan. Selain itu, responden juga mengetahui berbagai elemen yang ada dalam sosialisasi, seperti elemen komunikator, komunikan, pesan, saluran dan noise.

Nilai rata-rata (mean) atas jawaban responden secara keseluruhan pada komponen afektif adalah sebesar 2,6. Mean pada komponen afektif tergolong dalam kategori positif, karena berada pada interval ke dua. Dengan demikian, tingkat persetujuan pelanggan listrik pascabayar adalah tinggi.

Komponen afektif menyangkut masalah emosional subjektif seseorang terhadap suatu objek sikap (Azwar, 2011: 24). Mayoritas responden dalam penelitian ini menyetujui adanya sosialisasi program listrik pintar PT PLN (Persero) Ranting Bangkalan. Responden menyetujui berbagai elemen yang ada dalam sosialisasi, seperti elemen komunikator, komunikan, pesan, saluran dan noise. 
Nilai rata-rata (mean) atas jawaban responden secara keseluruhan pada komponen konatif adalah sebesar 2. Mean pada komponen konatif tergolong dalam kategori negatif, karena berada pada interval pertama. Dengan demikian, kecenderungan pelanggan listrik pascabayar untuk menggunakan listrik pintar adalah negatif.

Komponen perilaku atau komponen konatif dalam struktur sikap menunjukkan bagaimana perilaku atau kecenderungan perilaku yang ada dalam diri seseorang berkaitan dengan objek sikap yang dihadapinya (Azwar, 2011: 28). Mayoritas responden dalam penelitian ini tidak memiliki kecenderungan untuk beralih kepada listrik pintar walaupun mengetahui dan menyetujui adanya program sosialisasi program listrik pintar. Rendahnya komponen konatif, memiliki berbagai faktor yang dapat memengaruhi, salah satunya adalah faktor kebiasaan responden menggunakan listrik meteran.

Pada kenyataannya dalam penelitian ini, timbul pengetahuan dan persetujuan yang tinggi mengenai sosialisasi program listrik pintar namun tidak muncul niat untuk menggunakan listrik pintar sebagai pengganti listrik meteran. Secara keseluruhan, hasil sikap adalah negatif karena kurang dari 2,51 menurut skala interval pengukuran sikap.

\section{KESIMPULAN}

Dari hasil penelitian dan pembahasan pada bab sebelumnya, sikap pelanggan listrik pascabayar Kabupaten Bangkalan mengenai sosialisasi program listrik pintar secara keseluruhan cenderung negatif. Berikut merupakan penjabaran sikap pelanggan listrik pascabayar mengenai sosialisasi program listrik pintar PT PLN (Persero) Ranting Bangkalan.

Pada sikap komponen kognitif secara keseluruhan, responden memiliki tingkat pengetahuan yang positif. Hal ini menunjukkan bahwa responden mengetahui sosialisasi program listrik pintar yang ditinjau dari segi elemen komunikasi dalam sosialisasi.

Pada komponen afektif secara kseluruhan, responden memiliki tingkat persetujuan yang positif. Hal ini menunjukkan bahwa responden menyetujui adanya sosialisasi program listrik pintar yang ditinjau dari segi elemen komunikasi dalam sosialisasi.

Pada komponen konatif secara keseluruhan, responden memiliki kecenderungan untuk berperilaku yang negatif. Hal ini menunjukkan bahwa responden tidak ingin beralih ke listrik pintar walaupun mudah melakukan pembayaran, lebih mudah dalam mengatur rekening listrik dan dapat mengatur sesuai dengan anggaran belanja. 
Dari hasil analisis jawaban responden, penelitian ini telah menjawab pertanyaan dalam rumusan masalah penelitian. Jawaban dari rumusan masalah tersebut ialah pelanggan listrik pascabayar tidak mendukung adanya sosialisasi program listrik pintar. Sehingga secara keseluruhan memiliki arah sikap yang negatif. Pelanggan listrik pascabayar mengetahui, menyetujui namun tidak memiliki kecenderungan untuk beralih.

\section{SARAN}

Secara akademis, untuk penelitian selanjutnya agar dapat dilakukan penelitian studi kasus. Sehingga dapat memperdalam faktor-faktor yang mempengaruhi responden serta memperdalam teori sosialisasi dan komponen yang terdapat didalamnya.

Secara praktis, bagi perusahaan yang akan melakukan sosialisasi mengenai program maupun kebijakan kepada masyarakat. Terlebih dahulu memperhatikan bagaimana karakteristik dari masyarakat. Terutama dari segi melalui apa sosialisasi tersebut dilakukan, sehingga dapat memilih saluran yang tepat dan efektif. Khususnya PT PLN (Persero) Ranting Bangkalan untuk mengemas strategi baru sesuai dengan target sosialisasi.

\section{DAFTAR PUSTAKA}

Alo liliweri, 2011. Komunikasi Serba Ada Serba Makna, Jakarta: Prenada Media Group
Azwar, S. 2011. Sikap Manusia Teori dan Pengukurannya, Yogyakarta : Pustaka Pelajar.

Badan Pusat Statistik Kabupaten Bangkalan. 2017. Kabupaten Bangkalan Dalam Angka. BPS Kabupaten Bangkalan.

Beebe, Steven A., Susan J. Beebe and Diana K. Ivy. 2010. Communication

Principles For A Lifetime. Boston: Allyn\& Bacon Publishing

Danandjaja. 2012. Metodologi Penelitian Sosial. Yogyakarta: Graha Ilmu

DeVito, Joseph A. 2013 . The Interpersonal Communication Book. edisi 13. Pearson Educations, Inc

Effendy, Onong, Uchjana. 2007. Ilmu, Teori, dan Filsafat Komunikasi. Bandung : PT. Citra Aditya Bakti.

Hurlock, E. B. (1980). Psikologi Perkembangan Suatu Pendekatan Sepanjang Rentang Kehidupan, Edisi 5. Jakarta: Erlangga.

Kriyantono, Rachmat. 2012. Teknik Praktis Riset Komunikasi. Malang: Prenada Media Group.

Rifai, Mien Ahmad. 2007. Manusia Madura: Pembawaan, Perilaku, Etos Kerja, Penampilan, dan Pandangan Hidupnya seperti Dicitrakan Peribahasanya. Yogyakarta: Pilar Media (Anggota IKAPI)

Robbins, Stephen P. \& Timothy A. Judge. 2013. Organizational Behavior. 15 Edition, USA: Pearson International Edition, Prentice -Hall.

Ruslan,Rosady. 2016. Manajemen Public Relatoins \& Media Komunikasi. Jakarta : PT Rajagrafindo Persada. Sujarweni, V dan Poly Endrayanto. 2012. Statistika untuk Penelitian. Yogyakarta: Graha Ilmu. 
Ulber Silalahi. 2012. Metode Penelitian Sosial. Bandung: PT. Refika Aditama.

\section{Sumber Jurnal}

Arriandi, Christian. 2014. Presepsi Remaja Terhadap Sosialisasi Pacaran Sehat Sebagai Pendidikan Seks Oleh Crisis Center Cahaya Mentari Surabaya. Surabaya: Universitas Kristen Petra.

Halim, Aditya Pranata. 2015. Sikap Komunitas Alumni Akademi Komunitas Mengenai Aktivitas Corporate Social Responsibility Akademi Komunitas PT. PJB. Surabaya: Universitas Kristen Petra

Kananto, Grace Greina. 2015. Sikap Konsumen pada Servicescape Coco Palm Grill Surabaya. Surabaya: Universitas Kristen Petra

\section{Sumber Wawancara}

Dwi Kusnanto. (2017, 4 Agustus). General Manager PT PLN (Persero) Distribusi Jawa Timur

Endang Wahyuni. (2017, 20 Juli). Karyawan Humas PT PLN (Persero) Distribusi Jawa Timur

Irawan. (2017, 23 Oktober). Pelanggan listrik meteran Kabupaten Bangkalan

Maulidya. (2017, 24 Februari). Pelanggan listrik pintar Kabupaten Bangkalan

Pinto Raharjo. (2017, 20 Juli). Deputi Manager Komunikasi Dan Bina Lingkungan PT PLN (Persero) Distribusi Jawa Timur

Umar Arif (2017, 24 Februari). Manager PT PLN Ranting Bangkalan

Yanuwar. (2017, 24 Februari). Pelanggan listrik meteran Kabupaten Bangkalan

\section{Sumber lain}

Josiandi, Agus. (2016, 27 Januari). Tunggakan Listrik Rayon Bangkalan Mencapai Rp8,5 Miliar. Diakses pada tanggal 7 Februari 2017.

http://jatim.metrotvnews.com/read/ 2016/01/27/475416/tunggakanlistrik-rayon-bangkalan-mencapairp8-5-miliar

Musthofa, Bisri. 2016. Nagih Listrik, Manager PLN di Madura 'Dibayar' Celurit. Diakses pada tanggal 7 Februari 2017. https://m.tempo.co/read/news/2016/ 01/27/058739667/nagih-listrikmanager-pln-di-madura-dibayarcelurit

Madura Rekor Tunggakan PLN Tertinggi SeIndonesia. (2014. 27 Oktober) Diakses pada tanggal 7 Februari 2017.

http://radarmadura.co.id/2014/10/m adura-rekor-tunggakan-plntertinggi-se-indonesia/. Diakses pada tanggal 7 Februari 2017

https://rumushitung.com/2013/06/08/tabel-rstatistika-dan-cara-membacanya/. Diakses pada tanggal 1 Desember 2017

www.pln.co.id, diakses pada tanggal 15 Februari 2017. 